\title{
Microstructure and Mechanical Properties of Cold Metal Transfer Welding AA6082-T4 Alloys
}

\author{
S. Balamurugan*, R. Ramamoorthi, I.K. Kavin Jeysing, S. Kumar, I. Mohammed Sharukhan, \\ G. Muthu Prakash and S. Madhan \\ Department of Mechanical Engineering, Sri Krishna College of Engineering and Technology, Coimbatore, India; \\ sambalamurugan@gmail.com
}

\begin{abstract}
Objectives/methods: Robot-assisted cold metal transfer (CMT) welding is being a relatively innovative method for joining metal which can be used in automotive industry, shipbuilding industry, aerospace, and many more to join similar and dissimilar metals. CMT welding was carried out on similar $5 \mathrm{~mm}$ thick AA6082-T4 alloy metal with $1.2 \mathrm{~mm}$ diameter ER5356 electrode wire as the filler metal. This work was focused on the results of the welding speed on the microstructure and mechanical properties of welded joints. Three welding speed 10,15, and $20 \mathrm{~mm} / \mathrm{s}$, respectively had chosen. The ASTM E8M-04 standard was used in order to cut all the welded specimens to analyse the tensile strength and the elongation of the welded joints. The hardness of the welded joints on the specimen was measured by using the Vickers microhardness testing machine. Scanning electron microscopy (SEM) was used to analyse the morphology of the surface and failure pattern of the tensile tested specimens. Findings/application: Results showed that CMT welding provides better welding joint efficiency with increasing in the welding speed, excellent tensile strength, and superior ductility.
\end{abstract}

Keywords: Microstructure, Hardness, CMT Welding, Strength

\section{Introduction}

Utilisation of aluminum alloys had increased in the automotive industry, which is a growing demand for fuel efficient and lightweight vehicles. A complete aluminum car body design allows weight savings up to $30-40 \%$. Industries like automobile and aerospace uses the AA6082-T4 alloys due to its properties like low density, high specific strength, and good corrosion resistance. 2 In the automotive, Shipbuilding and aerospace industry, etc., welding is one of the essential joining processes as considering the fabrication process. Materials like Al$\mathrm{Mg}-\mathrm{Si}$ alloys are readily weldable, even though a series of weld defects may take place during welding process. For instance, in the traditional welding process an extreme heat was generated which causes heat affected zone to softening because of precipitation process reversed which involved in the artificial ageing.

AA6082-T4 is the weldable alloys generally welded using traditional and non-traditional welding processes.
To weld aluminum and its alloys Tungsten Inert-Gas (TIG) and Metal Inert-Gas (MIG) are welding processes mostly preferred to weld aluminum and its alloys due to their simplicity in nature, high quality welds attained, versatility, quickness of welding? $\underline{\underline{3}}$ While in view of developments in MIG technology, the cold metal transfer (CMT) technology provides good weld efficiency, versatility and energy efficiency due to low heat produced during welding and these together makes the novel welding process for joining aluminum parts. $\underline{4}$

CMT is a computerised welding process which essentially based on the concept of dip transfer welding processes, which is specified by controlled material deposition during the short circuit of the wire electrode of the machine and to the weld specimen. In the evaluation with the pulsed MIG welding, CMT needs lesser current for the same amount of material deposition. Thicker material sections can be welded when combining CMT welding with conventional pulsed welding which provides greater material deposition and increased penetration..$^{\frac{5}{}}$

${ }^{*}$ Author for correspondence 
The CMT process has a very low short-circuit current, and thus, low heat input. The current was maintained low by controlling of short-circuit during the welding process, resulting in the practically almost spatter free transfer. CMT is used in applications that benefit from low voltage and amperage and reduced thermal input. 6 Due to the minor thermal heat input, the ability of gap bridging, small dilution, speedy operation, and low spatter offered by CMT welding compared with other welding techniques, it is referred one of the attractive and shows potential for joining such difficult to weld aluminum alloys. ${ }^{\underline{7}}$

Ahmad and Bakar ${ }^{8}$ have examined the combined effect of the post-weld heat treatment on AA6061 alloy samples. In this study, the CMT welded specimen was categorised into two, such as as-welded and PWHT. The various processes applied on the PWHT were solution heat treated process, water quenching and artificial ageing on the specimen. The results were showed that the PWHT specimen attained higher mechanical property and microstructure behaviour. Gungor et al. 9 have investigated 5083-H111 and 6082-T651 aluminum alloys material in the robotic CMT-assisted MIG welding. The results showed that, CMT-MIG offers a good joint efficiency with increasing in the welding speed along with superior tensile and fatigue performance.

Selvamani et al. $\underline{10}$ have developed the Empirical Relationship to Predict Maximum Tensile Strength on AA 7075 CMT Welded Al Alloy. In this work, very fineequiaxed grains were observed in the fusion zone; no defects were observed throughout the weldment area and the maximum strength was predicted to be $402 \mathrm{Mpa}$ which is achieved under the welding condition of current of $90 \mathrm{~A}$, voltage of $12.5 \mathrm{~V}$, and welding speed of $275 \mathrm{~mm} /$ min in the CMT welding process. Azar 11 has proposed a heat source model for CMT-assisted welding process. Applying this model over the weld pool will also provide the welding research with broader information about the Marangoni convection inside the weld area and pool as a function of varying arc parameters.

From the literature review, it is clearly understood that more research to be focused on the effect CMT welding parameters. Though there were many recent progresses in the robot-assisted CMT welding process for joining variety of materials yet there is no sufficient technical reports regarding the AA 6082-T4 alloy joints mechanical properties and the microstructural characteristics. AA 6082 is one of the medium strength alloys with excellent corrosion resistance and also used in highly engineered applications such as Trusses, Transport applications, Bridges, etc. Hence, in this research work, CMT welding has done on AA6082-T4 alloy with three welding speed 10,15 , and $20 \mathrm{~mm} / \mathrm{s}$, respectively and the influence of welding speed during CMT welding on microstructure and mechanical properties of welded joints were investigated.

\section{Research Methodology}

A $5 \mathrm{~mm}$ thick AA 6082-T4 alloy has used in this work and ER 5356 electrode wire with a diameter of 1.2 $\mathrm{mm}$ was actively used as the filler metal. The nominal chemical compositions of material being welded and mechanical properties of the aluminum alloy and wire are listed in Tables 1 and 2, respectively. The AA 6082-T4 alloy has sliced into several pieces with breadths of 100 mm according to the ASTME8M 04 standards. Milling machine has used to prepare grooving with an angle of $30^{\circ}$ for each part according to ISO 9692 as shown in Figures 1 and 2.

Fronius CMT advanced 4000R welding system has a remote control unit to control the wire feed speed. The complete CMT welding process parameters are shown in

Table 2. Mechanical properties of AA6082-T4 and electrode wire 5356

\begin{tabular}{|l|l|l|l|l|}
\hline Materials & $\begin{array}{l}\text { Elastic } \\
\text { modulus } \\
(\mathbf{G P a})\end{array}$ & $\begin{array}{l}\text { Yield } \\
\text { strength } \\
(\mathbf{M P a})\end{array}$ & $\begin{array}{l}\text { Ultimate } \\
\text { tensile } \\
\text { strength } \\
(\mathbf{M P a})\end{array}$ & $\begin{array}{l}\text { Elongation } \\
\text { rate (\%) }\end{array}$ \\
\hline AA6082-T4 & 70 & 110 & 205 & 14 \\
\hline ER5356 & 65 & 85 & 200 & 17 \\
\hline
\end{tabular}

Table 1. Chemical compositions of AA6082-T4 and electrode wire 5356 (wt.\%)

\begin{tabular}{|l|l|l|l|l|l|l|l|l|l|}
\hline Materials & $\mathbf{M g}$ & $\mathbf{S i}$ & $\mathbf{C u}$ & $\mathbf{F e}$ & $\mathbf{M n}$ & $\mathbf{Z n}$ & $\mathbf{T i}$ & $\mathbf{C r}$ & Al \\
\hline AA6082-T4 & $0.6-1.2$ & $0.7-1.3$ & 0.1 & 0.5 & $0.4-1.0$ & 0.2 & 0.1 & 0.25 & Bal. \\
\hline ER5356 & 4.5 & 0.25 & 0.1 & 0.4 & 0.05 & 0.1 & 0.06 & 0.05 & Bal. \\
\hline
\end{tabular}




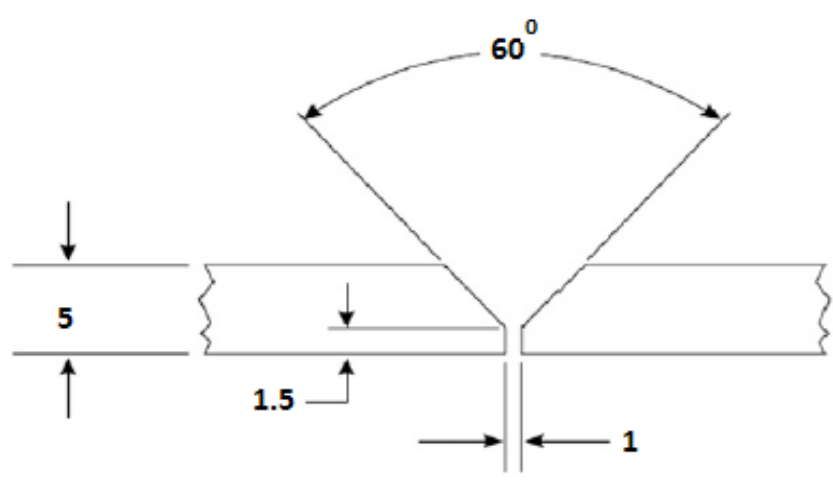

Figure 1. Single V groove joint ( $\mathrm{mm}$ ) as per ISO 9692 weld joint preparation.

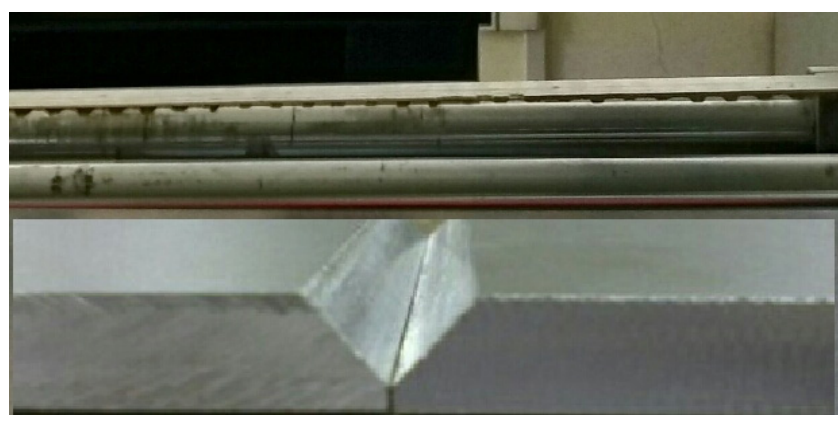

Figure 2. Finished grooving for welding.

Table 3, and in this investigation the parameters used in CMT welding process were optimised in a series of preexperiments. Before welding, alcohol was used to clean the base material to remove impurities such as dust, oil, and grease that are normally present after the cutting and grooving process to ensure the better welding process. $\underline{12}$

Welded specimens were arranged for the tensile test according to the ASTM E8M 04 standard. A CNC wire

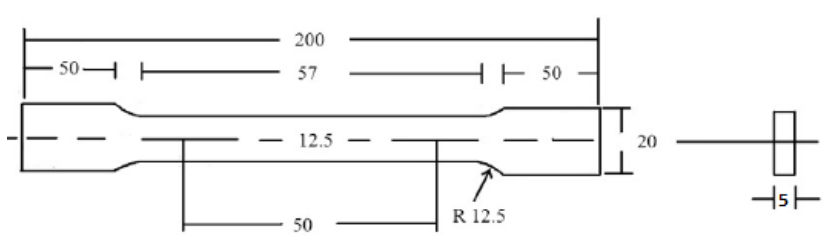

Figure 3. Tensile test dimension ( $\mathrm{mm})$.

EDM machine was employed to cut the welded samples into the specific dimensions, as shown in Figure 3. Tensile specimens were taken to Universal Testing Machine and testing was carried out at $100 \mathrm{kN}$ and a cross head speed of $1.50 \mathrm{~mm} \mathrm{~min}^{-1}$, at room temperature. Scanning electron microscopy (SEM) used to study the fracture surface and the morphology of the welded specimens. Hardness was measured at three different zones on the samples using Vickers microhardness tester with a load of $0.2 \mathrm{~kg}$ and a dwell time of $15 \mathrm{~s}$.

Table 3 shows CMT welding parameters providing the different range of heat input to the specimen during welding. Among all the welding variables in arc welding processes, the current used in welding is the most influential variable since it has an effect on the current density and thus the melting rate of the filler wire and also affects the base material. So in accordance with this fundamental fact, three different heat input corresponding to different welding currents i.e., $60 \mathrm{~A}, 90 \mathrm{~A}$, and $120 \mathrm{~A}$ were chosen in this study. There were two reasons for using these specific welding current values was spectrum of heat input combinations results in arc energies which are sufficient to cause adequate fusion of the base and weld metal selected for the present study and a step increase of 30 A was anticipated to be sufficient enough to cause a

Table 3. Process parameters during CMT welding

\begin{tabular}{|c|c|c|c|c|c|c|c|}
\hline Filler & Base metal & No & Current (A) & Voltage (V) & $\begin{array}{l}\text { Welding } \\
\text { speed }(\mathrm{mm} / \mathrm{s})\end{array}$ & $\begin{array}{l}\text { Wire feed rate } \\
(\mathrm{m} / \mathrm{min})\end{array}$ & Heat input $(\mathrm{kJ} / \mathrm{mm})$ \\
\hline \multirow{9}{*}{ ER5356 } & \multirow{9}{*}{ AA6082-T4 } & 1 & 60 & 14 & 10 & 5.3 & 0.076 \\
\hline & & 2 & 90 & 14.9 & 10 & 6.5 & 0.122 \\
\hline & & 3 & 120 & 15.8 & 10 & 7.2 & 0.171 \\
\hline & & 4 & 60 & 14.4 & 15 & 6.5 & 0.052 \\
\hline & & 5 & 90 & 15.2 & 15 & 7.2 & 0.082 \\
\hline & & 6 & 120 & 15.6 & 15 & 5.3 & 0.112 \\
\hline & & 7 & 60 & 14.2 & 20 & 7.2 & 0.038 \\
\hline & & 8 & 90 & 15 & 20 & 5.3 & 0.061 \\
\hline & & 9 & 120 & 15.9 & 20 & 6.5 & 0.086 \\
\hline
\end{tabular}


direct and significant influence on the microstructure and tensile properties of the welded joints. $\underline{13}$

\section{Results and Discussion}

\subsection{Mechanical Properties}

Robot-assisted CMT welding process was designed by particular controller to controls the welding current at the time of arcing phase and the short circuit phase. The heat input can be calculated during welding in the weldment by the formula. $\underline{14}$

$$
\text { Heat input, } \mathrm{kJ} / \mathrm{mm}=\frac{\text { Voltage } \times \text { Current } \times k}{\text { Welding speed } \times 1000}
$$

where $k$ is the thermal efficiency factor for the welding process (was used $k=0.9$ ). Calculations for the heat input at various CMT welding current; CMT welding voltage and CMT welding speed are given in Table 3. The heat input was one of the significant parameters during welding which have highly influenced on micro and mechanical properties of a welded joint. Figure 4 shows the bar chart for various heat input during the CMT welding process with the effect of different CMT welding current and CMT welding speed. From Figure 4, it was inferred that a high heat input during CMT welding was generated for
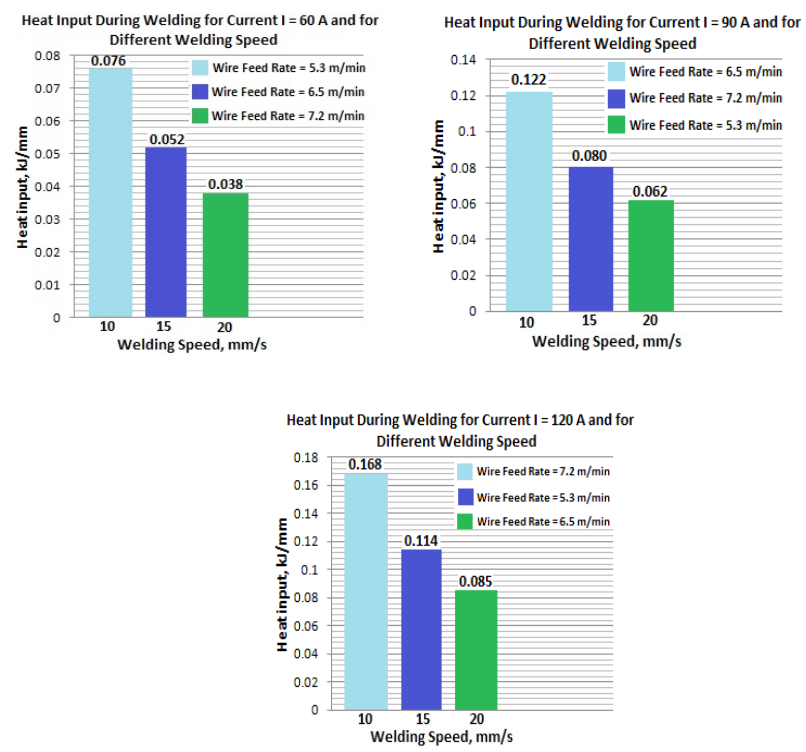

Figure 4. Heat input during welding with different welding current and speed. low welding speed and for all different welding current. A very low heat input was detected for high welding speed.

The effect of welding speed on the heat input is shown in Figure 5. A regression model was proposed to identify the response to the heat for different welding speed. A quadratic regression model was selected to infer the effect of welding speed on heat input. It is clearly observed from Figure 5 was that the heat input was high enough at low CMT welding speed and it was further lowered to increase in welding speed during the CMT welding process. It was further identified that the heat input is directly proportional to the robot-assisted CMT welding current and the arc voltage and it is inversely proportional to the welding speed. Increasing in the welding current and arc voltage during the CMT welding process would lead to increase in heat input. However, the condition would reverse if increasing welding speed.

The heat input that was given during CMT welding has the huge control on the micro and mechanical properties of the base material due to CMT welding. A higher input was given during CMT welding was created a wider softening region in the weld area which would affect the properties of weldment.

Four samples were used to calculate the mechanical behaviour of the welded specimen which was the tensile strength of the welded specimen. The averages of four stress values were considered for the calculation of tensile strength are shown in Figure 6. Tensile strength of welded specimen for 60 A welding current are 186, 191, and 198 $\mathrm{MPa}$ corresponding to welding speed 10,15 , and $20 \mathrm{~mm} / \mathrm{s}$, respectively. Similarly tensile strength was obtained for 90 $\mathrm{A}$ and $120 \mathrm{~A}$. CMT welding current corresponding to 10, 15 , and $20 \mathrm{~mm} / \mathrm{s}$ welding speed was observed and is shown in Figure 6. It was clear that, among three different CMT
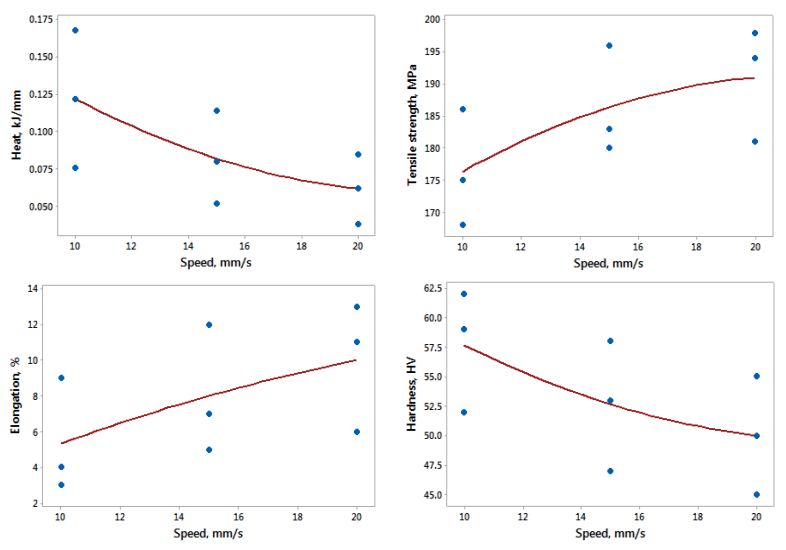

Figure 5. Fitted line plot. 


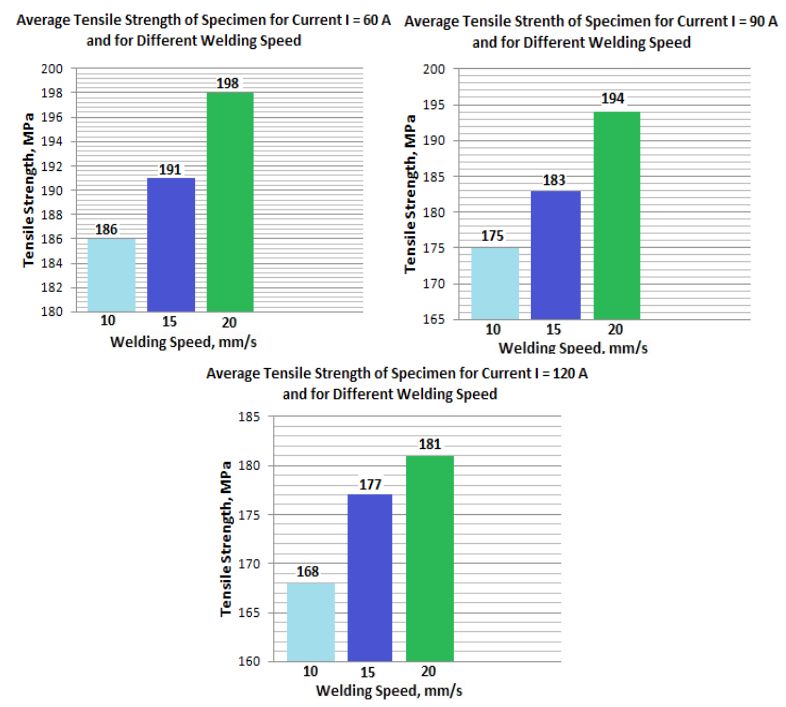

Figure 6. Tensile strength of specimen for different welding current and speed.

welding currents and CMT welding speed, a maximum of $198 \mathrm{MPa}$ of tensile strength was achieved for the CMT welding current $60 \mathrm{~A}$ and CMT welding speed $20 \mathrm{~mm} / \mathrm{s}$. It was further observed that for all three different welding current 60,90 , and $120 \mathrm{~A}$, the maximum tensile strength was attained only at a maximum CMT welding velocity of $20 \mathrm{~mm} / \mathrm{s}$.

The response of tensile strength behaviour for the CMT welded specimen was predicted by a quadratic regression equation. From Figure 5, it was very clear that the tensile strength of AA6082-T4 CMT welded specimen was gradually increases with the increase of the welding speed ranging from 10 to $20 \mathrm{~mm} / \mathrm{s}$. The reason is that heat input during welding has gradually decreased with increased in welding speed which enhances a sufficient penetration which leads to less distribution of stress concentration in the fusion line. Due to less stress concentration, an initial crack was not observed in the fusion line.

The robot-assisted CMT welding was conducted at 60 A CMT welding current and with three different welding speeds 10,15 , and $20 \mathrm{~mm} / \mathrm{s}$. A $2.67 \%$ increment in tensile strength was attained when the welding speed increased from 10 to $15 \mathrm{~mm} / \mathrm{s}$. Welding speed further increased from 15 to $20 \mathrm{~mm} / \mathrm{s}$, a $3.66 \%$ increment in tensile strength was achieved. Similar trend was achieved for welding current 90 and $120 \mathrm{~A}$, respectively. A highest $\%$ increment in tensile strength 6.01 was attained in $90 \mathrm{~A}$ welding current, when the welding speed increased from 15 to $20 \mathrm{~mm} / \mathrm{s}$.
Figure 7 shows the average percentage of elongation of the specimen for different welding speed. The highest average percentage of elongation was recorded as 13.62 , 11.34 , and $6.22 \%$ for the welding current 60,90 , and 120 A, respectively.

Elongation was increased with increased in the CMT welding speed. This was mainly due to decrease in CMT heat input. Increase in percentage of elongation achieved because AA6084 T4 it is known that the ductility of the material is obtained from the solution heat treated and naturally aged. In the CMT welding current $60 \mathrm{~A}$ and 20 $\mathrm{mm} / \mathrm{s}$ welding speed a superior $\%$ of elongation of the welded specimen was achieved evaluated with other two CMT welding speed 10 and $15 \mathrm{~mm} / \mathrm{s}$, respectively. This $60 \mathrm{~A}$ and $20 \mathrm{~mm} / \mathrm{s}$ combination was produced fine and equated recrystallised grain structure due to low heat input and which led to better elongation. At 90 A welding current, a maximum $\%$ of elongation was attained at 20 $\mathrm{mm} / \mathrm{s}$, similar trend was attained for the welding current $120 \mathrm{~A}$. At low welding speed excess heat was generated which produces turbulence effect in the plasticised metal zone. This results in the formation of heterogeneous which leads Si particles to broken down and gives lower elongation. A lowest percentage of elongation 3.12\% was recorded when the welding speed $10 \mathrm{~mm} / \mathrm{s}$ and welding current were $120 \mathrm{~A}$. This combination were provided high heat, such as $0.171 \mathrm{~kJ} / \mathrm{mm}$ on the base metal which then this reduces in ductility is mainly due to an increase in the barriers to flow that affect the steady state flow stress.

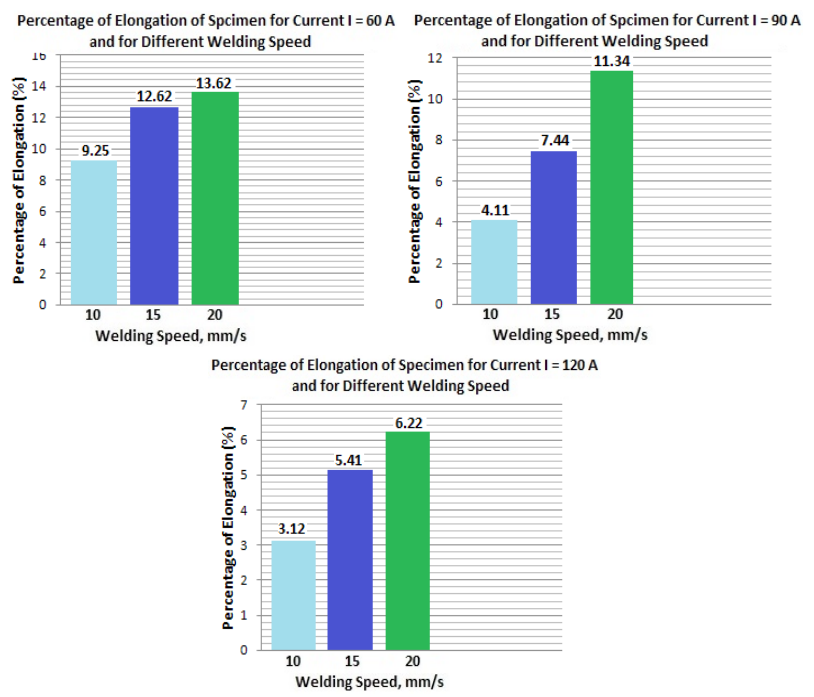

Figure 7. Percentage of elongation of specimen for different welding speed. 
Microhardness test was done on the welded surface by Vickers machine with a load of $0.2 \mathrm{~kg}$. The lowest hardness value was recorded in the weldment. In general, many factors which are influencing the material hardness of the weld area are grain size, precipitate volume fraction, and the alloying elements. Filler metal that was used in the CMT welding and the dilution which was happened during welding from the base metal are the combination during welding in the weld area. The base metal AA6082 alloy having low Mg and Si which leads in lower precipitation and also the lower amount of alloying elements. These were resulted in the decrease of hardness of the material in weld metal area. Figure 8 shows the average hardness value of the CMT welded specimen for different CMT welding speed. It was further clearly observed that the hardness of the welded material decreased with increased in the CMT welding speed. The maximum hardness during robot-assisted CMT welding $62 \mathrm{HV}$ was attained at $120 \mathrm{~A}$ welding current and 10 $\mathrm{mm} / \mathrm{s}$ welding speed among other two welding currents. Because of maximum heat $0.171 \mathrm{~kJ} / \mathrm{mm}$ was given in this position. Increased in the CMT welding heat input could enhance the formation of mar-tensite and increase the microhardness of HAZ. $\frac{15}{}$ Lowest hardness value was recorded as $45 \mathrm{HV}$ corresponding to $60 \mathrm{~A}$ and $20 \mathrm{~mm} / \mathrm{s}$ welding speed. Because of the minimum heat input as 0.038 $\mathrm{kJ} / \mathrm{mm}$ was given in this position. The hardness value of the material was a measure of the resistance of a material to indentation. Hardness value is the general response of different samples which mainly depends on the effect of

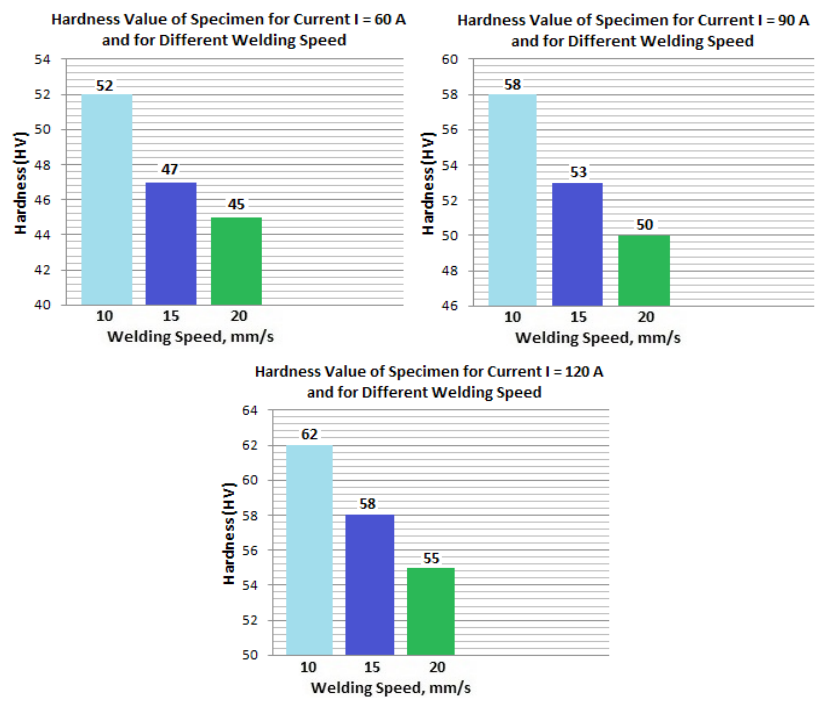

Figure 8. Average hardness value of specimen for different welding speed. precipitation that takes place at the microstructural level. This is due to low heat input because of low current given during welding when compared with other two currents.

The welding speed during CMT welding has a huge influence on the weldments properties and the effect of different welding speed on welded specimen is clearly shown in Figure 9. Weldment size and dimension, microstructure and mechanical properties are the key factors that are highly influenced by the welding speed. In order to achieve full penetration and adequate fusion of base metals, a high heat input is generally considered but to decrease weld distortion and phase transformation in the fusion and HAZ a low heat input is chosen. The welded area in the 90 A specimen had 25\% larger than the other welded area. A continuous penetration of the welded beads found in the specimen welded with $60 \mathrm{~A}$ current. Spatter is started to visible in the welded specimen at 90 A current with $15 \mathrm{~mm} / \mathrm{s}$ CMT welding speed during welding process. Additional spatters also were found with $20 \mathrm{~mm} / \mathrm{s}$ welding speed during CMT welding. An interrupted penetration was found with current $120 \mathrm{~A}$ along with the spatters. However, a well weld profile was observed in $90 \mathrm{~A}$ welding current corresponding to 10 $\mathrm{mm} / \mathrm{s}$ welding speed without any spatter. This joint was given reasonable hardness as $58 \mathrm{HV}$ and strength 175 $\mathrm{MPa}$ than all other joints.

\subsection{Fracture Surfaces}

Visual inspection of the tensile samples of welded specimen after fracture indicated that the fracture at all times occurred within the weld area and the fracture surfaces of the tensile specimens were examined using SEM to know the failure patterns of the welded AA6082-T4. Figure 10

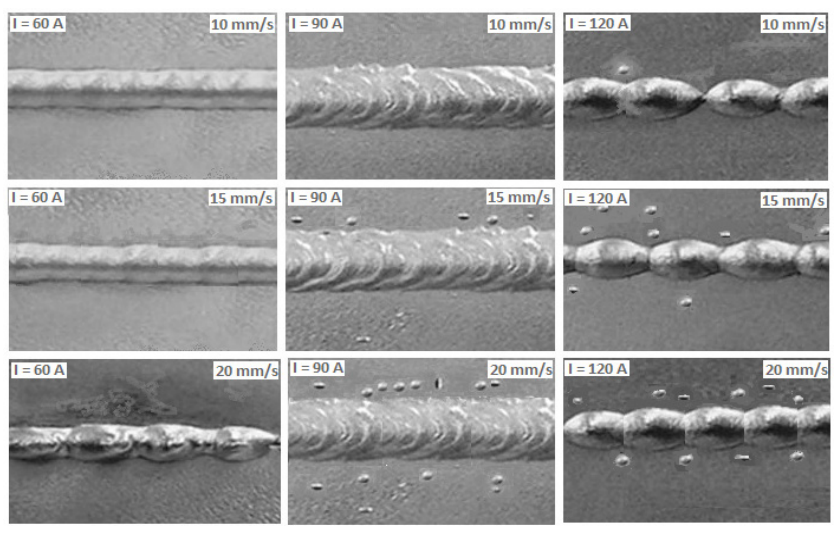

Figure 9. Bead profile of the welded specimen at various welding current and welding speed. 


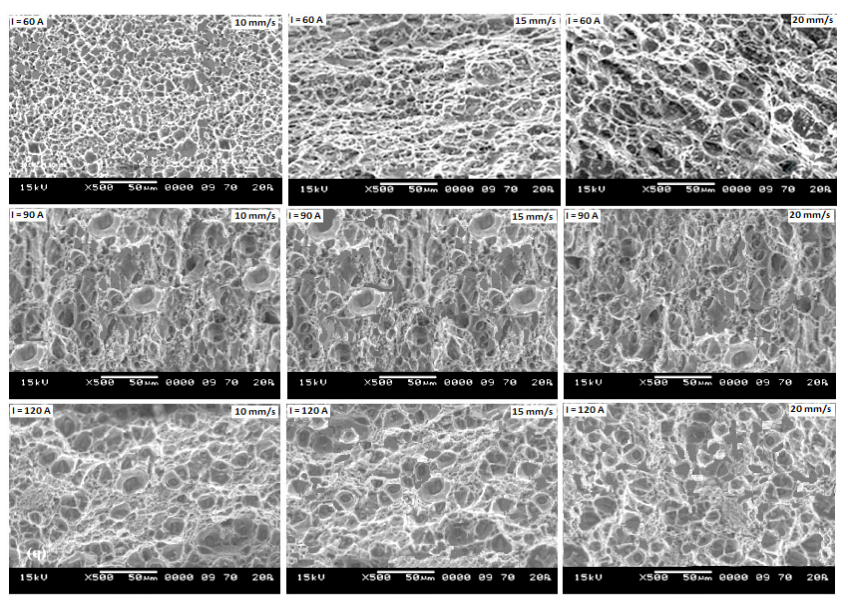

Figure 10. SEM fractographs of the welded joints at the speeds of $10 \mathrm{~mm} / \mathrm{s}, 15 \mathrm{~mm} / \mathrm{s}$, and $20 \mathrm{~mm} / \mathrm{s}$.

shows the SEM fractograph of the welded joints at the speeds of $10 \mathrm{~mm} / \mathrm{s}, 15 \mathrm{~mm} / \mathrm{s}$, and $20 \mathrm{~mm} / \mathrm{s}$ during welding with different heat input. Failure occurred in the weldment due to low hardness observed in that area when compared with the base metal. However, the welded joint micro and mechanical properties and fracture paths are controlled to a huge size by the Weldment composition. In view of the fact that, ER5356 electrode was used to weld AA6082-T4 metal and these resulted in less amount of alloying elements in the weldment then which improved the ductility of the joints and also maintaining optimum strength level.

From Figure 10, it was identified a type of pure-shear fracture mode. For the robot-assisted CMT welded joint at welding speed of $10 \mathrm{~mm} / \mathrm{s}$ and welding current $60 \mathrm{~A}$, many small dimples and some cleavage can be observed. Similarly, when the weld speed further increased to $15 \mathrm{~mm} / \mathrm{s}$ same pattern was observed. However, small dimples and large cleavage can be observed when the weld speed increased to $20 \mathrm{~mm} / \mathrm{s}$. It indicated that the welded specimen fails in the mixed fracture mode. When welding current increased to $90 \mathrm{~A}$, dimples surrounding with coarse dimples and cleavage can be observed. Same pattern was experienced for the CMT welding speed of 15 and $20 \mathrm{~mm} / \mathrm{s}$. For the welding current $120 \mathrm{~A}$, uneven size of dimples and large cleavage with smaller depth was observed for all three welding speed. So, it could be concluded that the welded specimen fails in ductile fracture mode at very low CMT welding speed and the material ductility was further improved along with the CMT welding speed during the welding process.

\section{Conclusion}

This work was investigated the effect of robot-assisted CMT welding speed on the microstructure and mechanical properties of AA6082-T4. From this work, the following conclusions are made:

- Microstructural examinations of CMT weld joints under different welding speed were carried out on AA6082-T4.

- Increasing in the CMT welding speed would lead to increasing in the mechanical properties of the welded material such as tensile strength and percentage of elongation for all three welding current.

- A $2.67 \%$ increment in tensile strength of welded material was achieved when the CMT welding speed further increased from 10 to $15 \mathrm{~mm} / \mathrm{s}$ during welding process. Welding speed again increased from 15 to 20 $\mathrm{mm} / \mathrm{s}$, a $3.66 \%$ increment in the tensile strength was gained for $60 \mathrm{~A}$ welding current and similar trend was attained for other two welding current.

- However, the hardness value was found that inversely proportional to the CMT welding speed for all three welding current during the welding process.

- The highest hardness of the welded material $62 \mathrm{HV}$ was observed at $120 \mathrm{~A}$ and $10 \mathrm{~mm} / \mathrm{s}$ welding speed among other two welding currents.

- The welded joints exposed minimum microhardness in the weldment as compared to the base metal.

- A well weld profile was observed in 90A welding current corresponding to $10 \mathrm{~mm} / \mathrm{s}$ welding speed without any spatter.

- Use of ER5356 electrode in welding AA6082-T4 was produced ductile fracture mode and was prolonged for all welding speed.

\section{References}

1. Hirsch J. Aluminium in innovative light-weight car design. Mater Trans. 2011;52(5):818-24.

2. Choi DH, Ahn BW, Lee CY, Yeon YM, Song K, Jung SB. Formation of intermetallic compounds in $\mathrm{Al}$ and $\mathrm{Mg}$ alloy interface during friction stir spot welding. Intermetallics. 2011;19(2):125-30.

3. El-Shennawy M, Abdel-Aziz K, Omar AA. Metallurgical and mechanical properties of heat treatable aluminum alloy AA6082 welds. Int J Appl Eng Res. 2017;12(11):2832-9.

4. Rosado T, Almeida P, Pires I. Innovations in arc welding. In: $5^{\circ}$ Congresso Luso-Moçambicano de Engenharia; 2008. P. 1-18. 
5. Pickin CG, Young K. Evaluation of cold metal transfer (CMT) process for welding aluminium alloy. Sci Technol Weld Joi. 2006;11(5):583-5.

6. Kah P, Jibril A, Martikainen J, Suoranta R. Process possibility of welding thin aluminium alloys. Int J Mech Mater Eng. 2012;7(3):232-42.

7. Elrefaey A. Effectiveness of cold metal transfer process for welding 7075 aluminium alloys. Sci Technol Weld Joi. 2015;20(4):280-85.

8. Ahmad R, Bakar MA. Effect of a post-weld heat treatment on the mechanical and microstructure properties of AA6061 joints welded by the gas metal arc welding cold metal transfer method. Mater Des. 2011;32(10):5120-26.

9. Gungor B, Kaluc E, Taban E, SIK ŞŞA. Mechanical and microstructural properties of robotic Cold Metal Transfer (CMT) welded 5083-H111 and 6082-T651 aluminum alloys. Mater Des. 2014;54:207-11.

10. Selvamani ST, Govindarajan P, Ajaymohan M, Hariharan SJ, Vigneshwar M. Developing empirical relationship to predict maximum tensile strength on AA 7075 CMT welded $\mathrm{Al}$ alloy. In: The 3rd international conference on materials and manufacturing engineering; 2018. vol. 390, P. $1-7$.

11. Azar AS. A heat source model for cold metal transfer (CMT) welding. J Therm Anal Calorim. 2015;122(2):741-6.

12. Tian Y, Shen J, Hu S, Liang Y, Bai P. Effects of ultrasonic peening treatment on surface quality of CMT-welds of $\mathrm{Al}$ alloys. J Mater Process Technol. 2018;254(11):193-200.

13. Kumar S, Shahi AS. Effect of heat input on the microstructure and mechanical properties of gas tungsten arc welded AISI 304 stainless steel joints. Mater Des. 2011;32(6):3617-23.

14. Rahul SG. Model reference adaptive controller for enhancing depth of penetration and bead width during cold metal transfer joining process. Robot Comput Integr Manuf. 2018;53(3):122-34.

15. Amer AE, Koo MY, Lee KH, Kim SH, Hong SH. Effect of welding heat input on microstructure and mechanical properties of simulated HAZ in Cu containing microalloyed steel. J Mater Sci. 2010;45(5):1248-54. 